\title{
RESPONS TOKOH PEREMPUAN TERHADAP IDEOLOGI PATRIARKI DALAM NOVEL ENTROK KARYA OKKY MADASARI: SUATU KAJIAN FEMINIS
}

\begin{abstract}
Sherly Yunityas
ABSTRAK

Penelitian ini bertujuan untuk menunjukkan adanya respons tokoh perempuan terhadap ideologi patriarki dalam novel Entrok karya Okky Madasari. Penelitian dilakukan dengan mencari ideologi patriarki pada lembaga-lembaga yang terdapat di dalam novel Entrok. Untuk menunjukkan adanya respons tokoh perempuan, peneliti menggunakan teori respon Stuart Hall sebagai pisau analisis yang utama. Stuart Hall membagi posisi masyarakat dalam merespons acara televisi ke dalam tiga bentuk, yakni: The Dominanthegemonic Position (Posisi Terhegemoni Secara Dominan), The Negotiated Position (Posisi Negosiasi), dan The Oppositional Code (Posisi Oposisional). Posisi masyarakat yang demikian menimbulkan respon yang berbeda-beda. Respons yang timbul, yakni respons mengalah, bekerja sama, dan melawan. Hasil penelitian menunjukkan bahwa tokoh perempuan pada novel Entrok mampu untuk menyuarakan perlawanannya, tetapi tidak sanggup untuk menghindar dari penindasan ideologi patriarki yang ada pada lembaga. Meskipun tokoh perempuan telah melakukan ketiga jenis respon menurut Stuart Hall, ideologi patriarki tetap tidak terkalahkan. Tokoh perempuan dalam novel ini tetap mengalami kekalahan dalam dominasi ideologi patriarki. Tokoh perempuan merespons ideologi patriarki dengan mengalah dan menyerah.
\end{abstract}

Kata kunci: respons, ideologi patriarki, dan novel Entrok.

\section{PENDAHULUAN}

Sebuah karya sastra tercipta dari usaha merekam isi jiwa seorang sastrawan. Rekaman ini menggunakan alat bahasa. Olehsebab itu, sastra merupakan bentuk rekaman dengan bahasa yang akan disampaikan kepada orang lain (Soemardjo, 1988:5).Melalui karya sastra, pengarang ingin mengungkapkan masalah manusia. Ia melukiskan berbagai penderitaan manusia, perjuangan, kasih sayang, dan kebencian. Menurut Esten (1990:8), dengan karya sastra, pengarang ingin menampilkan nilai-nilai yang lebih tinggi dan lebih agung, serta menafsirkan makna hidup.Karya sastra mewujudkan impian pengarang untuk menciptakan dunia yang sesuai dengan keinginannya sendiri menjadi kenyataan. Sebagai hasil dari pengalaman melihat kenyataan sosial dikawinkan dengan imajinasi pengarang, terbentuklah karya sastra, sebuah dunia ciptaan sang pengarang.

Dalam berkehidupan, manusia dan karya sastra sebenarnya hanya berisi ai perpindahan dari satu lembaga masyarakat ke lembaga masyarakat lainnya. Lembaga merupakan tempat berproses menjalani hidup. Lembaga merupakan tempat sekelompok orang yang terorganisasi bertugas melaksanakan aktivitas lembaga tersebut. Lembaga juga dapat berarti sebuah tempat berkumpulnya masyarakat untuk melaksakan akivitas seharihari.Lembaga adalah relasi sosial yang relatif, terpola, dan tetap. Artinya, lembaga mengatur hubungan manusia dengan manusia lainnya dalam pola yang mengikat dan tetap. Pola yang dimaksud di sini merupakan konsep bersistem yang menjadi landasan sebagai 
arah dan tujuan lembaga tersebut. Konsep bersistem ini biasa disebut dengan ideologi. Salah satu ideologi yang sering menjadi dasar pengembangan tema dalam karya sastra adalah ideologi patriarki. Ideologi patriarki yang meletakkan kaum perempuan terdominasi dan tersubordinasi. Adapun kata patriarki secara harafiah berarti kekuasaan bapak atau patriarkh (patriarch).

Dalam sistem patriarki hubungan antara laki-laki dan perempuan bersifat hirarkis. Laki-laki berada pada kedudukan puncak dan mendominasi kaum perempuan. Sebaliknya, perempuan berada pada kedudukan bawah yang didominasi oleh laki-laki. Hal tersebut yang menyebabkan kaum laki-laki berhak menentukan kedudukan kaum perempuan. Sebaliknya, kaum perempuan tidak dapat menentukan kedudukan kaum laki-laki. Adanya hubungan yang bersifat hierarki tersebut menimbulkan kerugian di pihak kaum perempuan. Selanjutnya, hal ini dipahami sebagai sistem dari ideologi patriarki.

Ideologi patriarki berarti wacana yang mendominasi kesuperioran laki-laki terhadap kaum perempuan. Ideologi patriarki menanamkan bahwa kelemahan perempuan dan kekuatan laki-laki merupakan kodrat yang telah ada sejak lahir. Tak semua pihak dapat menerima ideologi patriarki pada lembaga yang dijalaninya. Hal ini disebabkan manusia memiliki cara merespons yang berbeda-beda dalam menanggapi sesuatu.

Okky Madasari merupakan salah satu penulis perempuan yang peka dan memilih caranya sendiri untuk merespons ketidakadilan patriarki di lembaga masyarakat yang dijalaninya. Ia melihat bahwa pada zaman orde baru (setting novel) lembaga masyarakat banyak yang melakukan ketidakadilan gender akibat pemahaman ideologi patriarki yang dibiarkan merajalela.

Perbedaan generasi membuat Marni dan Rahayu (tokoh dalam novel Entrok) menjalani lembaga dan menerima ideologi patriarki yang berbeda pula. Respons yang diberikan oleh Marni dan Rahayu dalam menghadapi setiap masalah di kehidupannya juga berbeda. Dalam penelitian ini digunakan teori respons John Storay untuk mengidentifikasi respons seperti apa yang diberikan oleh Marni dan Rahayu terhadap ideologi patriarki yang terdapat pada tiap-tiap lembaga yang mereka jalani.

\section{METODE PENELITIAN}

Penelitian ini meneliti respons tokoh perempuan pada novel Entrok melalui temuan-temuan cara tokoh perempuan menyuarakan tanggapannya lewat fokalisasi yang dilakukannya. Respons tokoh perempuan tersebut hadir tidak lain untuk menyikapi dominasi ideologi patriarki yang berada pada lembaga masyarakat. Adapun teori yang digunakan untuk meneliti respons pada novel Entrok adalah teori feminis yang membahas tentang ideologi patriarki dan teori fokalisasi untuk melihat sudut pandang penyuaraan bagaimana respons tokoh perempuan terhadap polemik ketidakadilan dominasi ideologi patriarki.

\section{HASIL DAN PEMBAHASAN}

Hubungan tokoh perempuan dengan ideologi lembaga patriarki yang terdapat dalam novel Entrokbaik secara langsung maupun tidak langsung menghalangi pergerakan Marni dalam mencapai impiannya. Setelah peneliti mengurutkan riwayat kejadian dalam novel, ditemukan beberapa lembaga masyarakat yang mengandung ideologi patriarki. Pendeskripsian ideologi patriarki pada lembaga masyarakat dipecah menjadi ideologi lembaga patriarki dengan hubungannya dengan Marni, dan ideologi lembaga patriarki dengan hubungannya dengan Rahayu.

Ideologi patriarki dilihat dari adanya ketimpangan, kekerasan, serta dampak kehidupan yang dihasilkan lembaga dalam mengekang pergerakan tokoh perempuan 
menjalani kehidupan sesuai dengan keinginannya. Adapun tokoh Marni masuk ke dalam lembaga keluarga, perkawinan, pekerjaan, militer, dan birokrasi. Tokoh Rahayu masuk ke dalam lembaga keluarga, perkawinan, militer, dan birokrasi.

Pada tiap-tiap lembaga, Marni menempatkan dirinya sebagai fokalisator internal. Artinya, Marni selaku tokoh menyaksikan langsung atau merasakan langsung ideologi lembaga patriarki yang terdapat pada Entrok. Kemudian, Marni menempatkan lembaga sebagai objek fokalisatornya. Pada lembaga keluarga dan perkawinan, Marni menempatkannya sebagai objek yang dilihat dari persepsi internal karena pada kenyataannya Marni merasakan langsung penyimpangan yang ada dan menindasnya. Selain itu, Marni juga banyak melihat objeknya dari persepsi eksternal dari dalam. Pada lembaga pekerjaan, militer, dan birokrasi, Marni menempatkannya sebagai objek yang dilihat dari persepsi eksternal dari luar yang artinya melihat objek hanya berdasarkan deskripsi lahiriah, seperti fisik dan kondisi yang terlihat dengan kasat mata.

Ideologi patriarki yang terdapat dalam novel Entrokbaik yang secara langsung maupun tidak langsung menindas Rahayu yakni ketimpangan yang terdapat pada lembaga Militer, keluarga, perkawinan, dan birokrasi. Pada tiap-tiap lembaga tersebut Rahayu menempatkan dirinya sebagai fokalisator internal dan terkadang sebagai fokalisator eksternal. Rahayu menempatkan diri sebagai fokalisator saat dirinya tengah melihat kondisi yang berkaitan dengan lembaga keluarga dan perkawinan. Padalembaga militer dan birokrasi, Rahayu lebih banyak menempatkan dirinya pada posisi fokalisator eksternal. Pada posisinya saat menjadi fokalisator internal, artinya Rahayu selaku tokoh menyaksikan langsung atau merasakan langsung penyimpangan relasi gender yang terdapat pada Entrok. Pada saat posisinya menjadi fokalisator eksternal, artinya Rahayu hanya sebagai narator yang artinya hanya sebagai pemerhati dariu luar kejadian penyimpangan relasi gender.

Rahayu menempatkan lembaga sebagai objek fokalisatornya. Pada lembaga keluarga dan perkawinan, Rahayu menempatkan lembaga tersebut sebagai objek yang dilihat dari persepsi internal karena pada kenyataannya Rahayu merasakan langsung penyimpangan yang ada dan menindasnya. Pada lembaga militer dan birokrasi dilihat Rahayu dari sisi objek eksternal bagian luar. Selain itu, Rahayu juga banyak melihat objeknya dari persepsi eksternal dari luar yang artinya melihat objek hanya berdasarkan deskripsi lahiriah, seperti fisik dan kondisi yang terlihat dengan kasat mata.

Dari posisinya melakukan fokalisasi, kedua tokoh, yakni Marni dan Rahayu dapat menunjukkan respons terhadap ideologi lembaga patriarki dalam novel Entrok. Pembagian analisis respons kedua tokoh perempuan adalah menurut teori Kajian media Stuart Hall mengenai respons jenis penonton televisi terhadap tayangan televisi, yakni The Dominanthegemonic Position (Posisi Terhegemoni Secara Dominan), The Negotiated Position (Posisi Negosiasi), dan The Oppositional Code (Posisi Oposisional).

Respons yang ditunjukkan oleh Rahayu saat dirinya menemukan dominasi ideologi patriarki yang sama pada tiap lembaga. Ideologi patriarki pada lembaga yang begitu mendominasi menimbulkan respons tunduk dan patuh Rahayu seperti pada lembaga militer, keluarga, perkawinan, dan birokrasi. Rahayu tidak berhasil melakukan perlawanan. dengan penerimaannya pada saat dirinya yang akan dijodohkan oleh Marni ibunya dengan tukang andong. Ini memperlihatkan adanya kepatuhan pada lembaga keluarga yakni hubungannya dengan sang ibu. Kemudian, kepasrahan Rahayu untuk dipoligami oleh Amri juga merupakan tanda yang memperlihatkan betapa Rahayu menerima ideologi patriarki yang terdapat pada lembaga tersebut.

Respons tokoh perempuan difokuskan pada fokalisator Marni dan Rahayu sebagai tokoh utama perempuan dalam novel. Dapat disimpulkan bahwa Marni banyak melakukan perlawanan terhadap setiap ideologi lembaga patriarki yang ia temui. Adapun Rahayu 
merespons dengan sikap tunduk dan negosiasi karena pada akhirnya kekuasaan hanya miliki pihak yang mendominasi. Ini merupakan sebuah ironi dimana Marni yang tidak pernah sekolah, tidak mengenal huruf dan pelajaran mengenai hak asasi manusia lebih melakukan pertahanan terhadap apa yang menjadi miliknya. Adapun Rahayu yang mencecap sekolah sampai perguruan tinggi tidak mampu berbuat apa-apa atas relasi tokoh dengan ideologi lembaga patriarki yang ia temukan.

\section{KESIMPULAN}

Respons tokoh perempuan terhadap ideologi lembaga patriarki dapat dilihat dengan bantuan dari fokalisator Marni dan Rahayu dalam novel. Dapat disimpulkan bahwa Marni dan Rahayu berada pada posisi terhegemoni yang berbeda-beda di setiap lembaga masyarakat. Marni lebih banyak menunjukkan respons terhadap ideologi lembaga patriarki yang dijalaninya, sedangkan Rahayu lebih banyak menunjukkan respons tunduk atau negosiasi. Ini merupakan sebuah ironi dimana Marni yang tidak pernah sekolah, tidak mengenal huruf, dan pelajaran mengenai hak asasi manusia lebih melakukan pertahanan terhadap sesuatu yang menjadi miliknya. Adapun Rahayu yang mencecap sekolah sampai perguruan tinggi tidak mampu berbuat apa-apa atas penindasan ideologi lembaga patriarki yang dilakukan kepadanya.

Rahayu juga tak dapat berbuat banyak terhadap ideologi lembaga patriarki yang menimpa lingkungan sekitar. Adapun Marni mengusahakan sekuat tenaga membela Rahayu dan pihak-pihak lainnya selain dirinya sendiri untuk terbebas dari ideologi lembaga patriarki yang mendominasi setiap kehidupan bermasyarakat dalam novel Entrok. Setiap tindakan, pemikiran yang dilakukan oleh Marni dan Rahayu bergerak ke arah yang berbeda. Rahayu tidak melibatkan logika dalam setiap keputusan yang diambil. Rahayu hanya memikirkan pengaruh dari keputusannya dan tindakannya itu dalam jangka pendek. Adapun Marni lebih berhati-hati dan dewasa dalam berpikir, bertindak, dan memutuskan sesuatu karena dia sadar akan pengaruhnya ke masa depan.

Penelitian mengenai respons tokoh peremuan terhadap ideologi lembaga patriarki menghasilkan sebuah kesimpulan yakni belum tentu generasi muda lebih baik daripada generasi sebelumnya. Generasi awal selalu memikirkan generasi muda ke depan dan bersedia melakukan segala cara termasuk melawan penindasan ideologi patriarki pada lembaga masyarakat demi tercapainya niat mulia tersebut. Generasi muda yakni diwakili oleh tokoh Rahayu melakukan perlawanan hanya sebatas kemampuannya sehingga hasil yang dibuahkan pun menjadi apa adanya. Sementara itu, generasi awal yang diwakili oleh Marni melakukan berbagai cara di luar batas kemampuannya, tak pernah menyerah sampai maksimal memperjuangkan hak-hak yang terlampau dibatasi oleh ideologi lembaga patriarki yang dijalannya.

\section{DAFTAR RUJUKAN}

Bhasin, Kamla. 1996. Menggugat Patriarki: Pengantar tentang Persoalan Dominasi terhadap Kaum Perempuan. Yogyakarta: Bentang Budaya.

Fakih, Mansour. 1997. Analisis Gender dan Transformasi Sosial. Cetakan II. Yogyakarta: Pustaka Pelajar.

Faruk, H.T. 1994. Pengantar Sosiologi Sastra. Yogyakarta: Pustaka Pelajar. 
Arkhais, Vol. 06 No. 1 Januari-Juni 2015

Jackson, Stevi. Pengantar Teori-Teori Feminis Kotemporer. Yogjakarta: Jala Sutra.

Kasiyan. 2008. Manipulasi dan Dehumanisasi Perempuan dalam Iklan. Jakarta: Ombak.

Kenan, Rimmon. 2002. Narrative Fiction Contemporary Poetics. Taylor \& Francis.

Madasari, Okky. 2006. Entrok. Jakarta: PT. Gramedia.

Musral, Esten. 1990. Sastra Indonesia dan Tradisi Subkultur. Bandung: Angkasa.

Nurgiyantoro, Burhan. 2002. Teori Pengkajian Fiksi. Yogyakarta: Gadjah Mada University Press.

Saryono, Djoko. 2009. Dasar Apresiasi Sastra. Jakarta: Almatera Publishing.

Soemardjo. 1988. Apresiasi Kesusastraan. Jakarta : PT. Gramedia.

Sugihastuti dan Itsna Hadi. 2007. Gender dan Inferiotas Perempuan. Jogjakarta: Pustaka Pelajar.

Sugihastuti dan Suharto. 2005. Kajian Sastra Feminis Teori dan Aplikasinya. Yogjakarta: Pustaka Pelajar.

Tim Sosiologi. 2007. Suatu Kajian Kehidupan Masyarakat. Jakarta: Ghalia Indonesia. 